\title{
スピネル型二酸化マンガン $\lambda-\mathrm{MnO}_{2}$ のイオン交換容量の 指標としての表面水酸基密度
}

\author{
田中 暁生 ${ }^{*}$ ，田村 紘基，古市隆三郎 \\ 北海道大学大学院工学研究科機能材料化学講座（干 060-8628 札幌市北区北 13 条西 8 丁目）

\section{Surface Hydroxyl Site Density on Spinel-type $\lambda-\mathrm{MnO}_{2}$ as a Measure of Ion-Exchange Capacity}

\author{
Akio TANAKA, ${ }^{*}$ Hiroki TAMURA, and Ryusaburo FURUICHI \\ Laboratory of Materials Chemistry, Graduate School of Engineering, Hokkaido University (Kita-13, Nishi-8, \\ Kita-ku, Sapporo 060-8628, Japan)
}

Received June 14, 1999 ; Accepted July 9, 1999

\begin{abstract}
Lambda-manganese dioxide $\left(\lambda-\mathrm{MnO}_{2}\right)$, a spinel-type oxide, has lattice vacancies with a size equal to that of lithium ions, and incorporates lithium ions selectively from aqueous solutions. Oxide surfaces in water are hydroxylated by hydration, and the surface hydroxyl groups adsorb ions non-selectively by ion exchange, interfering with the selective incorporation of lithium ions. In this investigation, the surface hydroxyl groups on $\lambda-\mathrm{MnO}_{2}$ were determined by the Grignard method as a measure of ion-exchange capacity. The surface hydroxyl site densities obtained were compared with the calculated value for the closest packing of hydroxyl groups, and the formation of hydroxyl groups was explained by neutralization of surface oxide ions by water.
\end{abstract}

Key Words : $\lambda-\mathrm{MnO}_{2}$, Lithium Ion, Hydroxyl Group, Ion-Exchange Capacity

\section{1 緒 言}

スピネル型酸化物である $\mathrm{Li}_{x} \mathrm{Mn}_{2} \mathrm{O}_{4}(0 \leqq x \leqq 1)$ は，リチウ ムイオンの拡散チャンネルとリチウムイオンを収容するサイ 卜を持ち, 格子構造を保持したままリチウムイオンを格子位 置に出し入れする，その祭，マンガンイオンの価数は，電荷 補償のため $x=1$ の時の +3.5 価から $x=0$ の時の +4 洒の間 で変化する. +4 洒のマンガンイオンとリチウム空格子から なる $x=0$ の酸化物 $\square \mathrm{Mn}_{2} \mathrm{O}_{4}$ ( $\square:$ 空孔)は $\lambda-\mathrm{MnO}_{2}$ と呼ば れ, リチウムイオン二次電池の電極材料になる ${ }^{11}$.

一方，このように特定のイオンを選択的に結晶格子位置に 取込む特性は，イオン交換の分野では“イオン記憶”あるい は“イオンふるい”と呼ばれ ${ }^{2-5)}$ ，いくつかの交換体が開発さ れている.大井らは，海水中のリチウムイオンの问収を目的 として, 各種スピネル型マンガン酸化物のリチウムイオン取 込み特性を研究した ${ }^{6-15)}$. 著者らは， $\lambda-\mathrm{MnO}_{2}$ によるリチウ ムイオンの取込みについて化学量論を確認するとともに取込 み速度挙動を検討し，そのモデル化を行った ${ }^{16)}$.

金属酸化物表面は一般に水中では水分子の解離吸着により 水酸基化し ${ }^{17-21)}$, 表面水酸基は，そのプロトンあるいは水酸 化物イオンとの交換により溶液から除陽イオンを吸着する。

著者らは各種酸化物による各種イオンの交換吸着挙動を検 討し, 独自の平衡論的手法で酸化物のイオン交換機能とイオ ンの酸化物親和性をモデル化し, 評価している22-24).その結 果によ札ば, 表面水酸基のイオン選択性は小さく, $\lambda-\mathrm{MnO}_{2}$
表面水酸基のイオン交換反応は格子空孔による選択的リチウ ムイオン回収を妨害するものと考之られる。

本研究では, $\lambda-\mathrm{MnO}_{2}$ 表面水酸基のイオン交換容量の指標 として二種類の試料の表面水酸基密度 $\left(N_{\mathrm{S}}\right)$ をグリニヤール 法によって測定し, 他の各種酸化物の值 ${ }^{25)}$ と比較検討した。そ の結果酸化物の相違による $N_{\mathrm{S}}$ の变化は小さく, その值は, 最 密充填した格子酸化物イオンが表面で水分子によって中和さ れて水酸基化するものとして説明できた。

\section{2. $1 \lambda-\mathrm{MnO}_{2}$ の調製}

\section{2 実 験}

$2 つ の \lambda-\mathrm{MnO}_{2}$ 試料を調製したが, いずれもスピネル型り チウムマンガン酸化物 $\left(\mathrm{LiMn}_{2} \mathrm{O}_{4}\right)$ からの硝酸溶液によるリ チウムイオン引拔き反応(1)によった。

$$
\begin{aligned}
4 \mathrm{LiMn}_{2} \mathrm{O}_{4}+8 \mathrm{H}^{+} \rightarrow 3 \square & \mathrm{Mn}(\mathrm{IV})_{2} \mathrm{O}_{4}\left(\lambda-\mathrm{MnO}_{2}\right) \\
& +4 \mathrm{Li}^{+}+2 \mathrm{Mn}^{2+}+4 \mathrm{H}_{2} \mathrm{O}
\end{aligned}
$$

試料 1

$\mathrm{KEE}$ 社 (東京) 製 $\mathrm{LiMn}_{2} \mathrm{O}_{4}$ から $1 \mathrm{~mol} \mathrm{dm}^{-3}$ 硝酸溶液に よりリチウムイオンを除去し, $\lambda-\mathrm{MnO}_{2}$ 試料 1 とした。 試料 2

炭酸リチウム (関東化学, 特級) と三二酸化マンガン (添 川理化学, $99.9 \%$ ) を $\mathrm{Li}: \mathrm{Mn}=1: 2$ (モル比) で混合し, $850{ }^{\circ} \mathrm{C} て ゙ 12$ 時間焼成したのち粉砕する工程を 5 回繰り返し, 次式の反応を行わせ $\mathrm{LiMn}_{2} \mathrm{O}_{4}$ を調製した。 


$$
\mathrm{Li}_{2} \mathrm{CO}_{3}+2 \mathrm{Mn}_{2} \mathrm{O}_{3} \rightarrow 2 \mathrm{LiMn}_{2} \mathrm{O}_{4}+\mathrm{CO}
$$

この $\mathrm{LiMn}_{2} \mathrm{O}_{4}$ を $1 \mathrm{~mol} \mathrm{dm}^{-3}$ の硝酸溶液に浸漬することに よりリチウムイオンを除去し, $\lambda-\mathrm{MnO}_{2}$ 試料 2 とした。

得られた試料は蒸留水で十分洗浄の後, $110{ }^{\circ} \mathrm{C}$ で 12 時間乾 燥しシリカゲルデシケータ中に保存した。

表面水酸基は，後述の上jに次式に従い格子酸化物イオン と水の反応によって生成する。

$$
-\mathrm{O}+\mathrm{H}_{2} \mathrm{O} \rightarrow-\mathrm{OH}(\mathrm{a})+-\mathrm{OH}(\mathrm{b})
$$

ここで- $\mathrm{OH}(\mathrm{a})$ は酸型表面水酸基, $-\mathrm{OH}(\mathrm{b})$ は塩基型表面水酸 基である. $110{ }^{\circ} \mathrm{C}$ の乾燥条件では非結合水は脱離するが, 生 成した表面水酸基は結合水としてそのまま残存するものと考 えられる ${ }^{26)}$.

\section{2. $2 \lambda \lambda-\mathrm{MnO}_{2}$ のキャラクタリゼーション}

化学分析

a.リチウムおよびマンガンイオン含有量

$\lambda-\mathrm{MnO}_{2}$ 試料 1 および 2 を塩酸ヒドロキシルアミン溶液 で還元溶解後，原子吸光法によりリチウムおよびマンガンの 含有量を求めた $\lambda-\mathrm{MnO}_{2}$ の試料 $1 \mathrm{~g}$ 当たりのそれぞれの含 有率を $f_{\mathrm{L} 1}$ および $f_{\mathrm{Mn}}\left(\mathrm{mol} \mathrm{g}^{-1}\right)$ とする。

b. $\mathrm{Mn}^{2+}$ までの還元に要する電子量

試料を硫酸酸性シュウ酸ナトリウム標準溶液で還元溶解し た後，残存するシュウ酸ナトリウムを過マンガン酸カリウム 標準溶液によって滴定した，消費されたシュウ酸ナトリウム 標準溶液量から電子の量を求为, 試料 $1 \mathrm{~g}$ 当たりの量 $e(\mathrm{~mol}$ $\left.\mathrm{g}^{-1}\right)$ を得た。試料中のマンガンイオンの洒数 $m$ は次式で与 えられる。

$$
m=e / f_{\mathrm{Mn}}+2
$$

得られた価数 $m$ とリチウム㧍よびマンガンイオンの含有率 $f_{\mathrm{L} 1}$ および $f_{\mathrm{Mn}}$ から化学組成を求奴。

$\underline{\text { SEM }}$

試料 1 および 2 につて酸化物の形態を FE-SEM (JOEL 社製，JSM-6300 F) により観察した。加速電圧は $5.0 \mathrm{kV}$ で，作動距離を $39 \mathrm{~mm}$ とした。

$\underline{\mathrm{XRD}}$

試料 1, 2 及び $\mathrm{LiMn}_{2} \mathrm{O}_{4}$ について, X'Pert (Philips 社)

を用い， $40 \mathrm{kV}-55 \mathrm{~mA} \mathrm{Cu}-\mathrm{K} \alpha$ 線で粉末 $\mathrm{X}$ 線回折 (XRD) を行った。

\section{BET 比表面積}

Gemini 2360 (Micromeritics 社) を用い， $\mathrm{N}_{2}$ 吸着により

\section{BET 比表面積を測定した.}

\section{3 表面水酸基量の測定}

金属酸化物の表面水酸基-OH は次式により Grignard 試 薬であるヨウ化メチルマグネシウム $\mathrm{CH}_{3} \mathrm{MgI}$ と $1: 1$ で反 応し，等量のメタン $\mathrm{CH}_{4}$ を発生する。

$$
-\mathrm{OH}+\mathrm{CH}_{3} \mathrm{MgI} \rightarrow-\mathrm{OMgI}+\mathrm{CH}_{4} \uparrow
$$

発生したメタンの量から表面水酸基量を求めた。

Fig. 1 は反応装置を示し，测定操作は次の通りである。

(a)丸底フラスコ反応容器 1 とビュレット 9 に恒温水 2 を循環 し $25^{\circ} \mathrm{C}$ とする.

(b)反応容器 1 に $0.15 \mathrm{dm}^{3}$ のジエチルエーテルを入れる.

(c) $\lambda-\mathrm{MnO}_{2}$ 試料 $0 \sim 4 \mathrm{~g}$ をスプーン 3 に取り, 反応容器 1 に セットする。

(d)過剩量の $\mathrm{CH}_{3} \mathrm{MgI}\left(0.8 \mathrm{~mol} \mathrm{dm}{ }^{-3}\right.$, 約 $\left.10 \mathrm{~cm}^{3}\right)$ を注射器

で反応溶液中に加え，スターラー 5 で㹂汼する。

(e)三方コック 8 をけ，ガスボンべ4 からメタンを反応溶液
に注入し飽和する，反応溶液からのエーテル蒸気とガスビュ レットからの水蒸気をドライアイストラップ 6 でトラップす る.

(f)三力コック 8 を開閉して, 反応容器とガスビュレットを大 気圧と平衡にする。

(g)ガスビュレットの水面が一定になったあと，コック8を閉 ビスプーンから試料を反応溶液中に落とし，反応を開始する。 (h) $\mathrm{NaCl}$ 飽和溶液 10 の水面をガスビュレットの水面と一致 させて，ビュレット内の圧力を大気圧と同一にし，発生した メタンの体積 $\left(\mathrm{cm}^{3}\right)$ を求める.

(i)標準状態 (STP) のメタンガス発生体積 $\left(\mathrm{cm}^{3}\right)$ を量 $(\mathrm{mol})$ に換算し, 反応式(1)加表面水酸基量 $(\mathrm{mol})$ を求好る。

\section{3 結果と考察}

\section{1 粒子形態}

$\lambda-\mathrm{MnO}_{2}$ 試料 1, 2 の SEM 写真を Fig. $2(\mathrm{a})$ 抢よび(b)に示 す. Fig. 2(a)から試料 1 の粒子の直径は 1 10 $\mu \mathrm{m}$ で大きさ に分布があるが，主体となる粒子の直径は $1 \mu \mathrm{m}$ である。ま

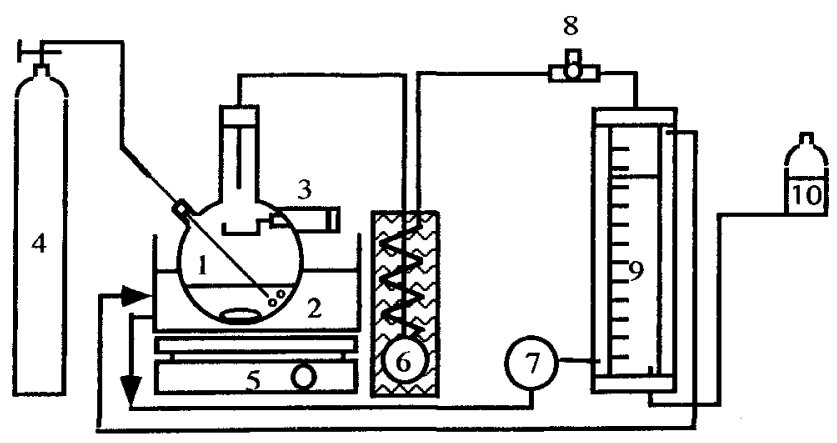

Fig. 1 Apparatus for the determination of the amount of surface hydroxyl groups on metal oxide by the Grignard method.

1. reaction flask 2. constant temperature water bath 3 . spoon 4. $\mathrm{CH}_{4}$ gas cylinder 5. magnetic stirrer 6. dry ice trap 7. water pump 8. three direction valve 9. gas burette $10 . \mathrm{NaCl}$ saturated solution.

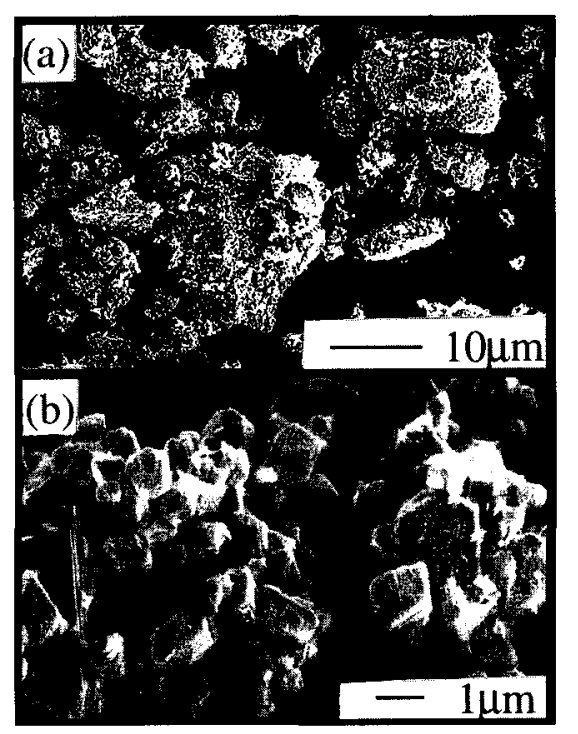

Fig. 2 Scanning electron micrographs of (a) sample 1 and (b) sample 2. 
Table 1 Results of chemical analysis and formula of sample 1 and sample 2.

\begin{tabular}{ccccc|c}
\hline & $f_{\mathrm{L} 1}[\mathrm{~mol} / \mathrm{g}]$ & $f_{\mathrm{Mn}}[\mathrm{mol} / \mathrm{g}]$ & $e[\mathrm{~mol} / \mathrm{g}]$ & $m$ & Formula \\
\hline Sample 1 & 0.000269 & 0.0113 & 0.02190 & 3.941 & $\mathrm{Li}_{0.0480} \mathrm{Mn}_{2.018} \mathrm{O}_{4}\left(\mathrm{H}_{2} \mathrm{O}\right)_{0.192}$ \\
Sample 2 & 0.000116 & 0.0115 & 0.02274 & 3.980 & $\mathrm{Li}_{0.0202} \mathrm{Mn}_{2.005} \mathrm{O}_{4}\left(\mathrm{H}_{2} \mathrm{O}\right)_{0.00740}$ \\
\hline
\end{tabular}

た, 表面は複雑な形態をとり内部のポア構造を示唆する.Fig. 2(b)から試料 2 の粒子の一辺は $1 \mu \mathrm{m}$ 程度の直方体で試料 1 よりも粒子の大きさはそろっている。ささら表面形態は試料 1 よりも平滑であるが，クラックが観察される.

\section{2 化学組成}

得られた $\lambda-\mathrm{MnO}_{2}$ の組成を $\mathrm{Li}_{x} \mathrm{Mn}_{y} \mathrm{O}_{4}\left(\mathrm{H}_{2} \mathrm{O}\right)_{z}$ と表すと, 電荷収支から

$$
x+m y=8
$$

さらに各イオンの含有分率 $f$ は次式で表される.

$$
\begin{aligned}
& f_{\mathrm{Li}}=x /(6.94 x+54.9 y+64+18 z) \\
& f_{\mathrm{Mn}}=y /(6.94 x+54.9 y+64+18 z)
\end{aligned}
$$

(6) 一 (8)式を組み合わせ, $f$ と $m$ の測定值を用いて $x, y$ およ び $z$ の值を求めた。試料 1 の組成は $\mathrm{Li}_{0.0480} \mathrm{Mn}_{2.018} \mathrm{O}_{4}$ $\left(\mathrm{H}_{2} \mathrm{O}\right)_{0.192}$, 試料 2 は $\mathrm{Li}_{0.0202} \mathrm{Mn}_{2.005} \mathrm{O}_{4}\left(\mathrm{H}_{2} \mathrm{O}\right)_{0.00740}$ と決定で きた(Table 1). 残存するリチウムの量はわずかで，組成的 に二酸化マンガンであることがわかる．試料 1 では水は表面 水酸基の他に構造中の結合水としても存在するものと考えら れた。

\section{3 結晶構造}

$\lambda-\mathrm{MnO}_{2}$ 試料 1,2 及び比較のために $\mathrm{LiMn}_{2} \mathrm{O}_{4}$ の XRD 図 をFig. 3(1)及び(2)に示す. $\mathrm{LiMn}_{2} \mathrm{O}_{4}$ のピークはいずれもス ピネル型構造の $\mathrm{LiMn}_{2} \mathrm{O}_{4}$ 単一相に相当する。これからリチ ウムイオンを除去して得られた $\lambda-\mathrm{MnO}_{2}$ 試料の $\mathrm{XRD}$ パタ ーンは $\mathrm{LiMn}_{2} \mathrm{O}_{4}$ に類似しスピネル型の構造を持ち, 確かに $\lambda-\mathrm{MnO}_{2}$ が生成していることを示す. $\lambda-\mathrm{MnO}_{2}$ の示すピーク 位置は $\mathrm{LiMn}_{2} \mathrm{O}_{4}$ より高角度側にシフトしており，リチウム イオンの除去により格子が縮んだことがわかる．このピーク 位置から格子定数 $a_{0}$ を求好ると, $\lambda-\mathrm{MnO}_{2}$ 試料 1 に関しては $0.8226 \mathrm{~nm}$ から $0.8038 \mathrm{~nm}$ へ, $\lambda-\mathrm{MnO}_{2}$ 試料 2 に関しては $0.8251 \mathrm{~nm}$ から $0.8028 \mathrm{~nm}$ へ減少した。

\section{4 比表面積}

BET 法により 5 回比表面積を测定し最大と最小を除去し 平均を取ると, $\lambda-\mathrm{MnO}_{2}$ 試料 1,2 の比表面積はそれぞれ 14.8 $\mathrm{m}^{2} \mathrm{~g}^{-1}, 7.65 \mathrm{~m}^{2} \mathrm{~g}^{-1}$ であった (Table 2).

$\lambda-\mathrm{MnO}_{2}$ の結晶粒子を一辺 $1 \mu \mathrm{m}$ の立方体と見なし, 密度 を $5.03 \mathrm{~g} \mathrm{~cm}^{-3}$ と仮定する ${ }^{27)}$ と, 表面積は $1.2 \mathrm{~m}^{2} \mathrm{~g}^{-1}$ と計 算される. BET 測定ではこれより大きな值が得られたが, 試 料 1 の表面形態が非常に複雑でポア構造が示唆されること, また試料 2 に関してはクラックが存在することから内部表面 が発達しているものと考えられる。

\section{5 表面水酸基密度 $\left(N_{\mathrm{S}}\right)$}

Grignard 法によるメタンの発生量 $(\mathrm{mol})$ と酸化物試料重 量 $(\mathrm{g})$ との関係を Fig. 4 に示す.いずれの試料についても 原点を通る直線になった。これらの直線の傾きは試料単位重 量当たりのメタン発生量，つまり水酸基量に当たり，それぞ れ試料 1 は $1.91 \times 10^{-4} \mathrm{~mol} \mathrm{~g} \mathrm{~g}^{-1}$, 試料 2 は $1.12 \times 10^{-4} \mathrm{~mol}$. $\mathrm{g}^{-1}$ である。

この単位重量当たりの表面水酸基量を比表面積で割り，表

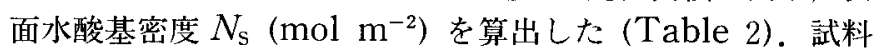

1,2 のそれぞれの表面水酸基密度は $1.29 \times 10^{-5}, 1.46 \times 10^{-5}$ mol m-2である. Table 2 には著者らが求めた各種酸化物 の $\mathrm{S}_{\mathrm{BET}}$ と表面水酸基密度 $N_{\mathrm{S}}$ の值を示す。 $\mathrm{S}_{\mathrm{BET}}$ の值は試料に より変化し, 最も大きい値と小さい值との間には 220 倍程度 の違いがあるが, $N_{\mathrm{s}}$ 值はいずれも $10^{-5} \mathrm{~mol} \mathrm{~m}-2$ のオーダー で，最大值と最小值の間の違いは3 倍程度にすぎない。

著者らは前報で次のような金属酸化物表面の水酸基化機構 を提案している ${ }^{25)}$.酸化物イオンは椣めて強い塩基で, 水中で そのままの形で存在できず, 次式のように水によって中和さ
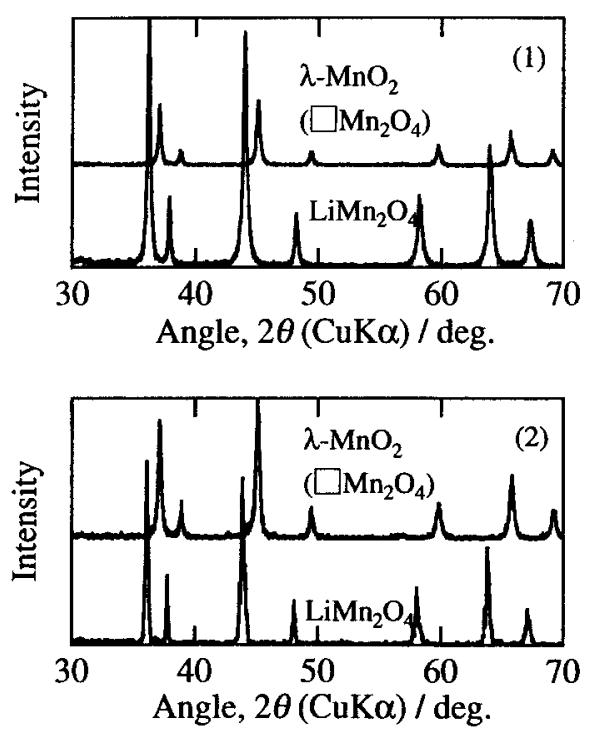

Fig. $3 \mathrm{XRD}$ patterns of (1) $\lambda-\mathrm{MnO}_{2}$ sample 1 and (2) $\lambda$ $-\mathrm{MnO}_{2}$ sample 2, as well as $\mathrm{LiMn}_{2} \mathrm{O}_{4}$.

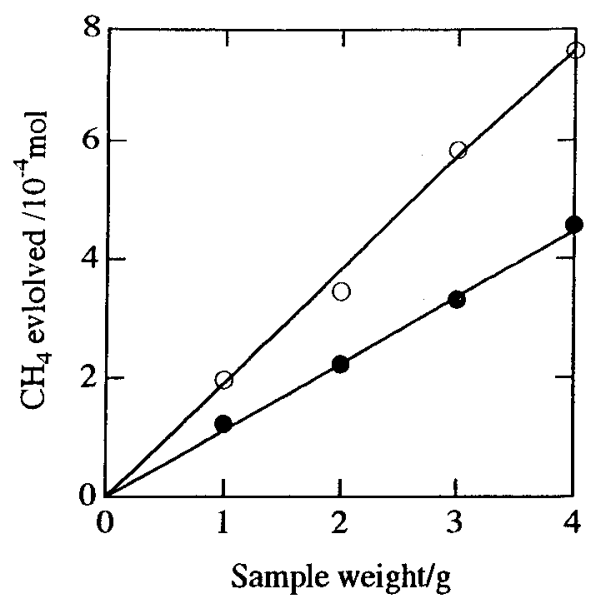

Fig. 4 Relationship between the amount of $\mathrm{CH}_{4}$ evolved and weight of $\lambda-\mathrm{MnO}_{2}$ samples. $\bigcirc \lambda-\mathrm{MnO}_{2}$ sample 1 , $\lambda-\mathrm{MnO}_{2}$ sample 2 . 
れ水酸化物イオンになる。

$$
\mathrm{O}^{2-}+\mathrm{H}_{2} \mathrm{O} \rightarrow 2 \mathrm{OH}^{-}
$$

金属酸化物表面には，サイズが大きく分極の小さな酸化物イ オンが䶘出するが28)，表面の酸化物イオンは格子金属イオン によって完全には中和されないので，水による中和を受け水 酸基化する。このとき，生成した水酸基は隣接する格子金属 イオンの数の違いにより酸型と塩基型に分かれる．以下に述 ベるように，この機構によれば表面の酸化物イオンは全て水 酸基化するので, どの酸化物も水酸基の最密充填密度に等し い同一の $N_{\mathrm{s}}$ 值を示すことになる.

酸および塩基型水酸基が上下 2 段に最密充填した場合を考 え，その平面図をFig. 5 に示す. 図中の三角形の中にある水 酸基の数は $1 / 2$ 倜であり，二段に水酸基が重なっていること を考えると上下合わせて 1 個である. 水酸化物イオンのイオ ン半徍を $r$ とし，三角形の面積を $S$ とすれば，

$$
S=\sqrt{3} r^{2}
$$

アボガドロ定数 $N_{\mathrm{A}}\left(6.02 \times 10^{23} \mathrm{~mol}^{-1}\right)$ を用いて単位面積当

Table 2 Specific surface area $S_{\mathrm{EET}}$ and hydroxyl site density $N_{\varsigma}$ of metal oxide samples.

\begin{tabular}{lcc}
\hline \multicolumn{1}{c}{ Sample } & $S_{\mathrm{BET}} / \mathrm{m}^{2} \mathrm{~g}^{-1}$ & $N_{\mathrm{S}} / \mathrm{mol} \mathrm{m}^{-2}$ \\
\hline$\lambda-\mathrm{MnO}_{2}$ (sample 1$)$ & 14.8 & $1.29 \times 10^{-5}$ \\
$\lambda-\mathrm{MnO}_{2}$ (sample 2) & 7.65 & $1.46 \times 10^{-5}$ \\
& & \\
$\mathrm{MnO}_{2}$ (IC1) & 43.0 & $2.25 \times 10^{-5}$ \\
$\mathrm{MnO}_{2}$ (IC12) & 80.0 & $2.35 \times 10^{-5}$ \\
$\mathrm{MnO}_{2}$ (IC22) & 45.1 & $2.41 \times 10^{-5}$ \\
& & \\
$\mathrm{Al}_{2} \mathrm{O}_{3}$ (ALO-4) & 155 & $3.20 \times 10^{-5}$ \\
$\mathrm{Cr}_{2} \mathrm{O}_{3}$ (Kanto) & 1.09 & $2.69 \times 10^{-5}$ \\
$\mathrm{Fe}_{2} \mathrm{O}_{3}$ (Kanto) & 5.60 & $2.36 \times 10^{-5}$ \\
$\mathrm{Fe}_{3} \mathrm{O}_{4}$ (Kanto) & 4.30 & $3.31 \times 10^{-5}$ \\
$\mathrm{SiO}_{2}$ (SIO-1) & 92.6 & $1.60 \times 10^{-5}$ \\
$\mathrm{SiO}_{2}$ (Kanto) & 245 & $0.954 \times 10^{-5}$ \\
$\mathrm{TiO}_{2}$ (TIO-5) & 21.5 & $1.16 \times 10^{-5}$ \\
$\mathrm{TiO}_{2}$ (Kanto) & 2.60 & $1.80 \times 10^{-5}$ \\
\hline
\end{tabular}

IC1, IC12, IC22 : International Common Samples for batteries, supplied from the IC Sample Office, Cleveland, OH, USA. ALO-4, SIO-1, TIO-5 : Reference Catalysts, supplied from the Catalysis Society of Japan.

Kanto: Kanto Chemical Co., Tokyo, Japan.

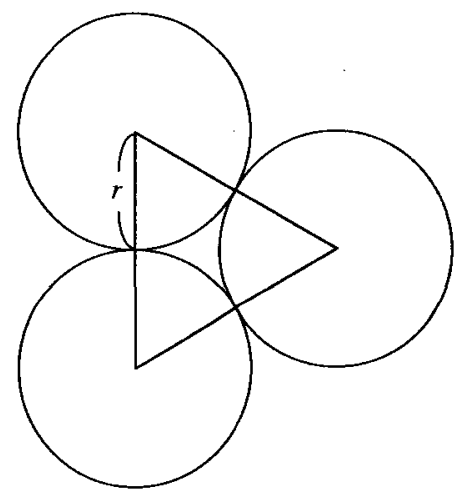

Fig. 5 Closest packing of hydroxyl ions with radius $r$.
たりの水酸基量（表面密度） $N_{\mathrm{S}}$ は次式によって求められる。 $N_{\mathrm{S}}=1 /\left(S \times N_{\mathrm{A}}\right)$

$r=1.45 \AA^{15)}\left(=1.45 \times 10^{-10} \mathrm{~m}\right)$ を代入すると, $N_{\mathrm{S}}=4.56 \times$ $10^{-5} \mathrm{~mol} \mathrm{~m} \mathrm{~m}^{-2}$ と計算される。この值はTable 2 の実測值を 説明するものである.

これまでに提案されている表面水酸基化の機構では，ルイ 又酸である格子金属イオンの水和により水酸基が生成寸るも のと考えている ${ }^{17-21)}$. この機構では, 格子金属イオンの酸化 数により酸化物中のその存在密度が異るので $N_{\mathrm{S}}$ 值が異なる ことになる。これは本研究の実测結果を説明することができ ず受け入れがたい。

Table 2 に示した表面水酸基密度から $\lambda-\mathrm{MnO}_{2}$ 格子空孔 へのリチウムイオン取込に対する非選択的イオン交換吸着の 妨害の程度を見積もることができる.大井ら ${ }^{14)}$ は $\mathrm{pH} 12$ に調 整した海水から $\lambda-\mathrm{MnO}_{2} 1 \mathrm{~g}$ 当たり $4 \times 10^{-4} \mathrm{~mol} の \mathrm{Li}$ 回収した。一方, 著者らは海水相当濃度の十トリウムイオン が $\mathrm{pH} 12$ で表面水酸基に飽和密度で吸着することを確かめ ている ${ }^{29)}$.すなわち, 海水からはリチウムイオンとともにナト リウムイオン (污染イオン) も吸着する. $\mathrm{pH}=12$ における海 水中での $\lambda-\mathrm{MnO}_{2} 1 \mathrm{~g}$ 当たりのナトリウムイオン吸着量を 求めると, 表面積は $10 \mathrm{~m}^{2}, N_{\mathrm{s}} \sim 1.4 \times 10^{-5} \mathrm{~mol} \mathrm{~m} \mathrm{~m}^{-2}$ の半 分がカチオン交換サイトなので $1.4 \times 10^{-5} \times 10 / 2=7 \times 10^{-5}$ $\mathrm{mol}$ となる。これはリチウムイオン取込量 $\left(4 \times 10^{-4} \mathrm{~mol}\right) の$ $18 \%$ に相当する。このような大きな割合の污染イオンの混入 をひき起こす表面水酸基の非選択的なイオン交換吸着を抑え るためには, $\mathrm{pH}$ を適切に制御するなど最適反応条件を求め る必要がある。

\section{4 結 論}

$\lambda-\mathrm{MnO}_{2}$ の表面水酸基量をグリニヤール法によって测定 し, 表面水酸基密度 $N_{\mathrm{S}}$ を得た. $N_{\mathrm{S}}$ 值は各種金属酸化物試料も

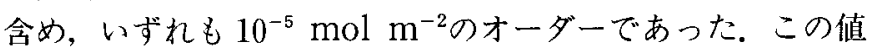
は，酸化物表面が酸化物イオンで終結し, 強い塩基である酸 化物イオンが水によって中和されて水酸基化するという機構 によって説明できる。

\section{謝 辞}

試料の提供をいただいた KEE 社, 栗林功氏に感謝いたし ます。

\section{文 献}

1) 芳尾真幸, 小沢昭弥編, リチウムイオン二次電池, 日刊工業新 聞社, p.5 (1996).

2) 妹尾 学, 阿部光雄, 鈴木 喬編, イオン交換体, 講談社, p.249 (1991).

3）鈴木 㑂, 電気化学 (presently Electrochemistry), 64, 342 (1996).

4) 馮 旗, 加納博文, 大井健太, 日本イオン交換学会誌, 8, 102 (1997).

5) 大井健太, ニュースレター(日本化学会コロイドおよび界面化 学部会), 23, [4], 6 (1998).

6) K. Ooi, Y. Miyai, and S. Katoh, Separation Science and Technol., 21, 755 (1986).

7) K. Ooi, Y. Miyai, and S. Katoh, Separation Science and Technol., 22, 1779 (1987).

8) K. Ooi, Y. Miyai, and S. Katoh, Solvent Extraction and Ion Exchange, 5, 561 (1987). 
9) K. Ooi, Y. Miyai, S. Katoh, H. Maeda, and M. Abe, Bull. Chem. Soc. Jpn., 61, 407 (1988).

10) Y. Miyai, K. Ooi, and S. Katoh, J. Colloid Interface Sci., 130, 535 (1989).

11) K. Ooi, Y. Miyai, S. Katoh, H. Maeda, and M. Abe, Langmuir, 5, 150 (1989).

12) Y-F. Liu, Q. Feng, and K. Ooi, J. Colloid Interface Sci., 163, 130 (1994).

13) Q. Feng, H. Katoh, Y. Miyai, and K. Ooi, Chemistry of Materials, 7, 148 (1995).

14）宮井良孝, 大井健太，加納博文，馮 旗，加藤俊作，四国工業 技術研究所研究報告, 第 28 号 (1996).

15）加藤俊作, 宮井良孝, 大井健太, 化学之工業, 42, 1787 (1998).

16）内保 顕, 田村紘基, 古市隆三郎, 分析化学, 44, 449 (1995).

17) P. Schindler, Adsorption of Inorganics at Solid-Liquid Interfaces, (Eds. M. A. Anderson and A. J. Rubin), Ann Arbor Science, Ann Arbor, Michigan, p.1 (1981).

18) R. O. James and G. A. Parks, Surface and Colloid Science, (Ed. E. Matijevic), Vol. 12, Plenum, New York, p.119 (1982).

19) P. W. Schindler and W. Stumm, Aquatic Surface
Chemistry, (Ed. W. Stumm), John Wiley \& Sons, New York, N. Y., p.87 (1987).

20) D. A. Dzombak and F. M. M. Morel, Surface Complexation Modeling, John Wiely \& Sons, New York, N. Y., p.45-46 (1990).

21) W. Stumm, Chemistry of the Solid-Water Interface, John Wiley \& Sons, New York, N. Y., p.13 (1992).

22) H. Tamura, N. Katayama, and R. Furuichi, Environ. Sci. Technol., 30, 1198 (1996).

23) H. Tamura, N. Katayama, and R. Furuichi, J. Colloid Interface Sci., 195, 192 (1997).

24) H. Tamura and R. Furuichi, J. Colloid Interface Sci., 195, 241 (1997).

25) H. Tamura, A. Tanaka, K. Mita, and R. Furuichi, $J$. Colloid Interface Sci., 209, 225 (1999).

26) J. A. Maxwell, Rock and Mineral Analysis, p.218, John Wiley \& Sons, New York, N. Y. (1968).

27）大木通則, 大沢利昭, 田中元治, 千原秀昭編集, 化学辞典, 東 京化学同人, p. 534 (1994).

28) H. P. Boehm, Discuss. Faraday Soc., 52, 264 (1971).

29）田中暁生, 田村紘基, 古市隆三郎, '98 北海道支部 (日本分析 化学会他）冬季研究発表会要旨集, p.72 (1998). 